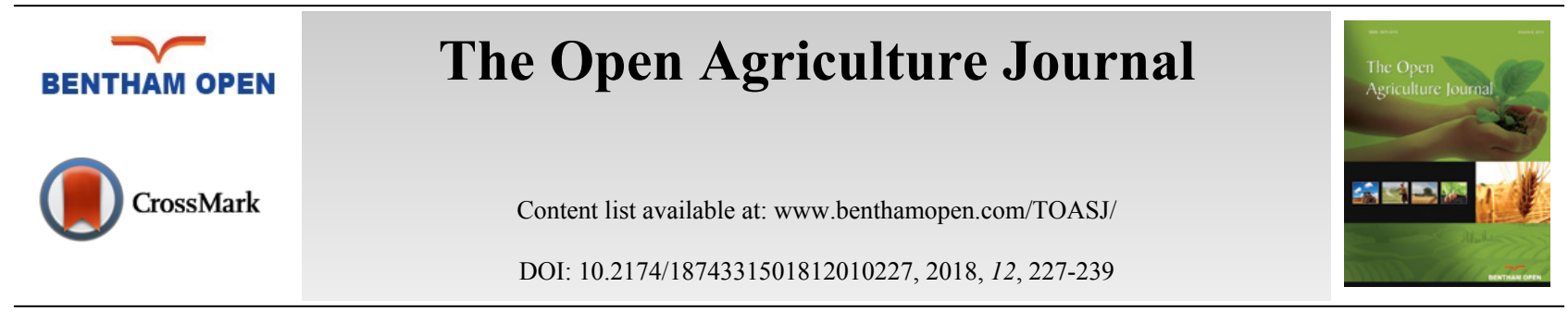

REVIEW ARTICLE

\title{
An Econometric Analysis of Food Security and Agricultural Credit Facilities in Nigeria
}

\author{
Romanus Osabohien ${ }^{*}$, Adesola Afolabi and Abigail Godwin \\ Department of Economics and Development Studies, College of Business and Social Sciences, Covenant University, \\ Ota, Nigeria
}

Received: June 13, 2018

Revised: June 28, 2018

Accepted: August 23, 2018

\section{Abstract: \\ Background:}

It is a known fact that the efficiency of credit facility positively contributes to production base of a sector, especially the Nigerian agricultural sector which is recognised as the heartbeat of the economy by employing over $70 \%$ of the country's labour force; this forms the motivation for this study.

\section{Objective:}

This study examined the potential of agricultural credit facilities in terms of commercial bank credit to agriculture and agricultural credit guarantee scheme fund (ACGSF) and their corresponding interest rates to farmers towards increasing agricultural production as the pathway to food security in Nigeria.

\section{Method:}

The study employed the Autoregressive Distribution Lag (ARDL) econometric approach on the time series data sourced from the Central Bank of Nigeria (CBN) statistical bulletin, Food and Agriculture Organisation (FAO) and the World Development Indicators (WDI) for the period 1990-2016.

\section{Result:}

The result from ARDL showed that commercial banks credits and ACGSF increased food security by $8.12 \%$ and $0.002 \%$ respectively, while population reduces food security by $0.001 \%$.

\section{Conclusion:}

The study concluded that population should be controlled through family planning and adequate financing of the ACFSF by the government and monitor commercial banks leading interest rates on credit facilities.

Keywords: Agriculture, Food Security, Credit Facility, ACGSF, ARDL, FAO.

\section{INTRODUCTION}

The efficiency and effectiveness of credit facility contribute immensely to production base of a sector, especially the Nigerian agricultural sector which is considered as the backbone of the economy [1]. The Nigerian agricultural sector employs more than one-third of the country's Gross Domestic Product (GD), provides approximately $75 \%$ of the rural employment and contributes about $35 \%$ to poverty reduction $[1,2]$.

\footnotetext{
* Address correspondence to this author at the Department of Economics and Development Studies, College of Business and Social Sciences, Covenant University, Ota, Nigeria; Tel: +2348064545217; E-mail: romanus.osabohien@covenantuniversity.edu.ng
} 
However, as argued by Mathius food production in developing countries has not been commensurate with the level of population growth; this is because the growth and competitiveness of the agricultural sector have been decreasing due to farmers' lack of credit facilities to attain the required level of production [3]. Provision of credit facilities to farmers has been widely recognised as an effective policy for the enhancement of food production to cater for the teeming population [4].

Inaccessibility of credit facility by farmers affects farm production in the sense that farmers experiencing capital constraint may tend to use a lower level of farm inputs in the production process $[1,2]$. On the other hand, sufficient access to credit facilitates by farmers improves input use on the farm and therefore have an import effect on agricultural productivity [5]. Thus, access to credit facilities enables farmers to satisfy their cash desires encouraged by the agricultural production cycle and consumption requirements [5]. For instance, it was noted that in Ghana, the incidence of food shortage in 2009 was fuelled by lack of agricultural credit facilities to farmers for the required level of food production [6].

It is widely believed in literature that to a large extent, food security is a function of an adequate food production as well as income to meet the households' nutritional level [7]. Agricultural credit facility to farmers could be in form of funds available to farmers to enable them buy the required farm inputs like; fertilizer, quality seeds, herbicides and pesticides into agricultural activities, and also enables them buy capital equipment like hoes, cutlasses, and water pumps has long been known to be some of the main hindrance of efficient food productivity in smallholder agriculture and lack of equipment to control emissions of greenhouse gases which damages crops and animals and negatively affect farmers health status $[8,7]$.

For over two decades, value addition per capita into the Nigerian agricultural has been crawling, rising by less in $1 \%$ per year. Food production gains have not kept pace with population growth currently with an estimated population of over 185 million people; this has resulted in the increased importation of food and reduced the standard of Nigeria independence in terms of food [1]. Also, good institutions and credit facility to adopt ICT by farmers will boost productive capacity of agricultural sector as adequate food production and supply are known to be necessary factors in the development process and indispensable factors in social and economic development and overall quality of life of the population in an economy [9].

Duong \& Izumida, in their study noted the importance of agricultural credit and pointed out that credit facilities geared towards the agricultural sector are aimed at increasing agricultural production [10]. They also noted that credit facilities granted to farmers has recognised to be the main investment expenditure towards the development of the Nigerian agricultural sector. The reduction of the Nigerian agricultural sector production capacity has which has led to the reduction of foreign exchange earnings can be linked to the deficiency of credit felicity policy and the shortage of data for credit institutions, which could help distribute facilities evenly [11].

As mentioned earlier, when agricultural inputs materials are made available, it is necessary, because credit to farmers are seen as another version of production material outside other inputs like labour, land, equipment and raw materials, which farmers rely on for productivity [12].

Osabohien et al. pointed out that agricultural credit facilities are not only necessitated by the restriction of the ability of self-finance, it also necessitated by the ambiguity relating to the level of farm input materials, production functions and the time spend between inputs and output [1]. This statement is validated in agricultural credit to households' model where the ineffective level of communication existing between the creditors and the debtors was noted, regulation of credit demand thus becomes essential for monetary organisations to affect agricultural credit facilities [13, $14]$.

However, credit regulatory policy tends to be regressive in nature with respect to the small-scale farm households in rural communities as it is associated with severe consequence for growth and equity purposes of growth strategy [15]. This is because when credit is controlled, some borrowers may not be able to secure the amount of credit required at the prevailing interest rate, nor be able to obtain more credit by offering to pay a higher interest rate. In such circumstances, liquidity can become a binding constraint on farmers' operations [15].

Access to agricultural credit has a specific characteristic of increasing food production which in turn increases food security; this is validated by the large proportion of the population (about $45 \%$ of total population) who lives in the rural areas with agriculture as their major occupation [1]. Thus, limited access to credit for farmers, especially those in rural communities imposes a high cost on the society in terms of the challenges of food security resulting from low 
production. This is also in terms of rural unemployment, rural poverty, and distortion of production and liquidation of assets [7]. Various administration attempts to improve the level of credit facilities by enacting some programmes for efficient access credit funds such as the agricultural credit guarantee fund schemes (ACGFS) in 1977, the specialised agricultural credit bank (e.g. NACB, 1973 now NACRDB, 2002) and the stimulating institutional innovations in the financial system (e.g. People's Bank, Community Bank, Rural Banking Schemes, among others [16]. Irrespective of these credit programmes, many banks perceive agricultural credit as risky and seek to channel credit to less risky business such as stock market among others, this behaviour may be due to the rational and efficient responses to information and contracting problems inherent in agricultural credit markets by the lenders [10].

Against this backdrop, this study aimed to evaluate the role of agricultural credit facilities in form of commercial bank credit to farmers and agricultural credit guarantee scheme funds to farmers in boosting agricultural productivity toward promoting food security in Nigeria. The study comprises of five sections, following this introductory section is a brief literature review which is stipulated in section two; section three encapsulates data and methods engaged for the analysis; section four presents the results and discussions and section five unveils the summary and conclusion.

\section{STYLISED FACTS AND EMPIRICAL LITERATURE}

\subsection{Stylised Facts}

The key concepts relating to this study is credit facility in form of commercial Bank credit and agricultural credit guarantee scheme fund, food security, and agricultural productivity are defined and discussed in this section.

This study tends to examine how credit facilities to agriculture in form of Commercial Bank Credit and agricultural credit guarantee scheme fund to the agricultural sector and its corresponding interest rate. Commercial banks credit to agriculture in Nigeria has been on the increase as observed in Fig. (1) [16]. From 1990 with a value of $\$ 4,221.4$ million to $\$ 25,278.7$ million in 1995 . As at 2000, it was valued at $\$ 41,028.9$ million which increased to $\$ 48,561.5$ million in 2005, then $\$ 128,406.0$ million in 2010 before reaching $\$ 316,364.0$ million in 2012 , and $\$ 478,911.78$ million as at 2014. By 2016, commercial banks’ credit to agriculture rose to $\$ 525,911.78$ million [16].

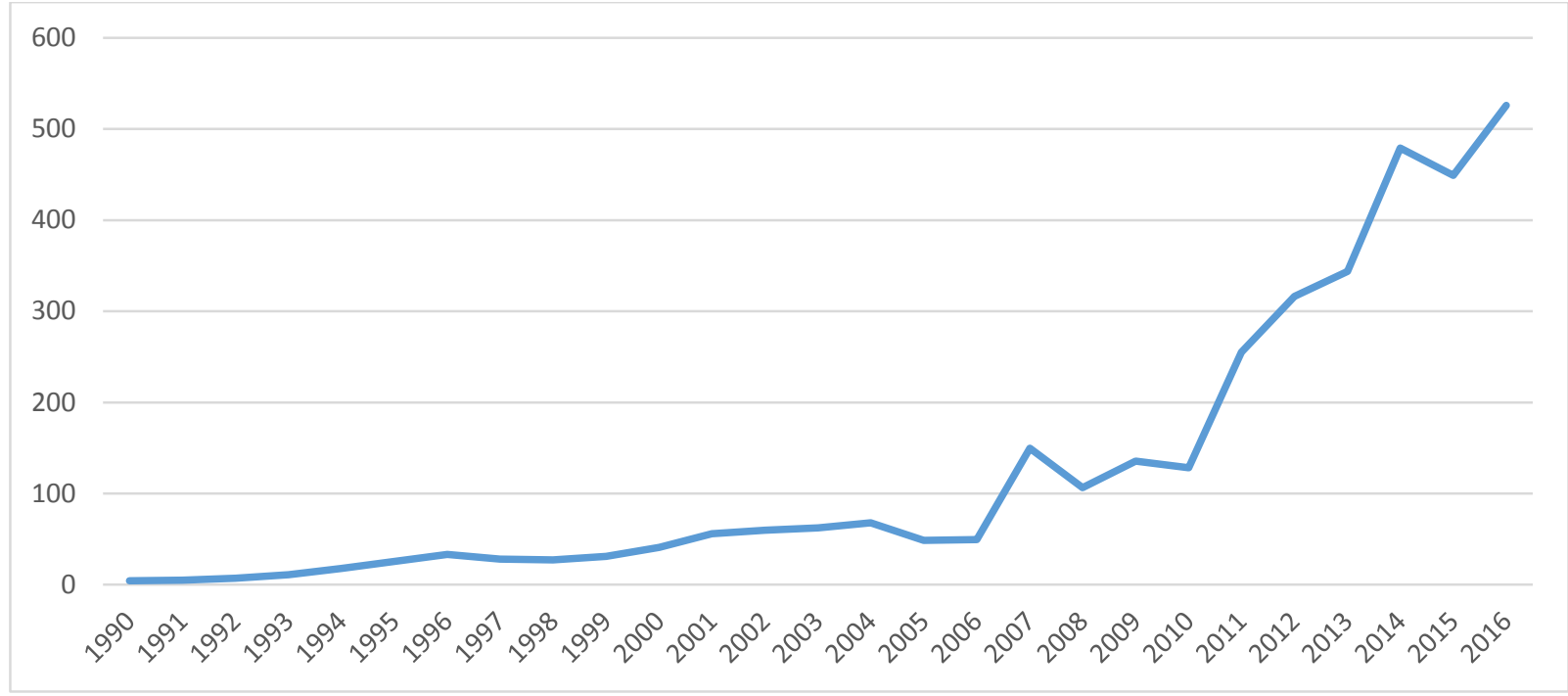

Fig. (1). Commercial Bank Credit to Agricultural Sector (bank credit). Source: Authors' computation using data from CBN Statistical Bulletin, 2016.

Statistics presented in Fig. (2) indicates that lending rate was $25.3 \%$ in 1990 but fell slightly to $17.80 \%$ in 1997 . The rate began an ascent in 1998 from $18.18 \%$ to $24.77 \%$ in 2002 ; when it began to fall slowly to $15.48 \%$ in 2008 . The rate later fluctuated between 2009 and 2011 before settling around 16\% as at 2016 the lending rate in Nigeria stood at $16.87 \%$. 


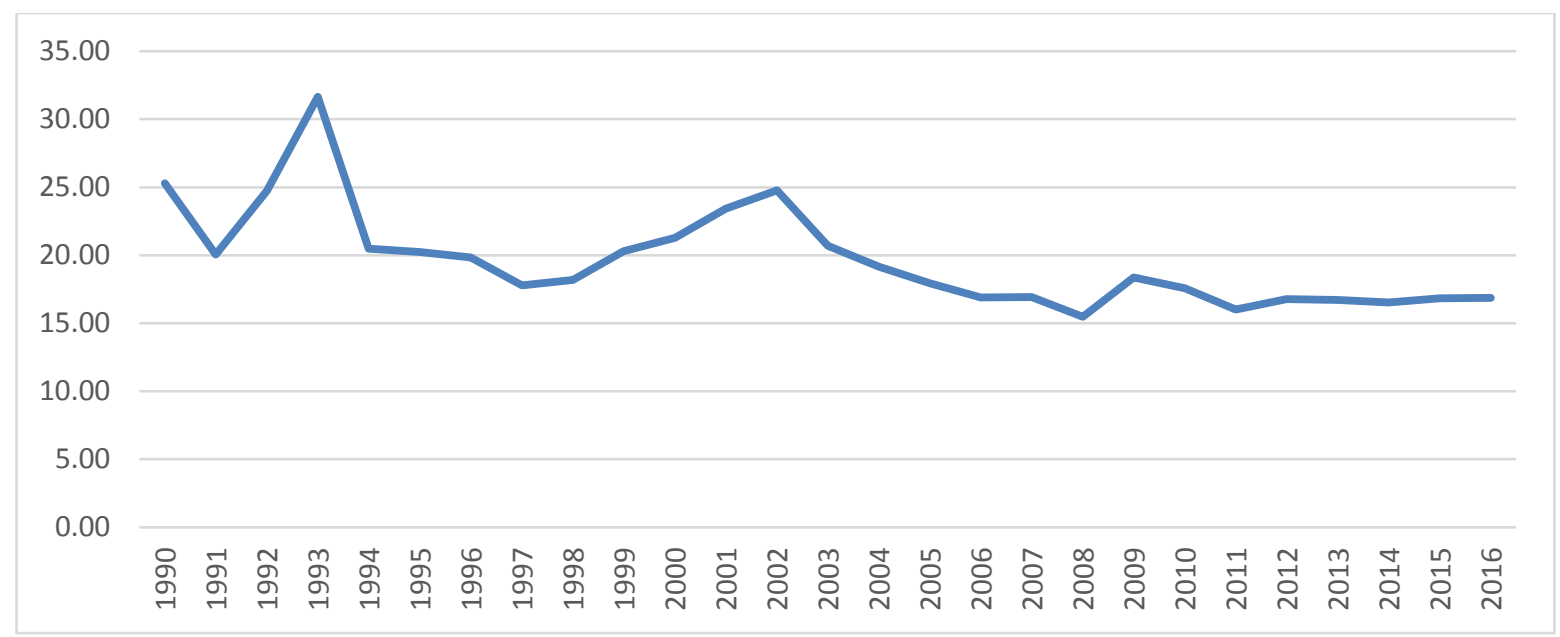

Fig. (2). Lending Interest Rate.

Source: Authors computation using data from WDI, CBN Statistical Bulletin, 2016.

Food security, however, refers to a situation that exists when all people, always have physical, social and economic access to sufficient, safe and nutritious food that meets their dietary needs and food preferences for an active and healthy life [17]. This definition points out the fact that there are four important dimensions of food security; availability, accessibility, utilisation, and stability, these four dimensions even though they overlap explain the phenomenon of food security, in this study, Food security was measured using depth of food deficit as a proxy for utilization.

Data, as presented in Fig. (3), showed that the depth of food deficit has been on a decline from 1990 [17]. It shows a trend analysis of the performance of the food security indicator over the 27 year period which has been on the decline from 134.00 calories in 1990 to 42.00 kilocalories in 2016. The value for Depth of the food deficit (kilocalories per person per day) in Nigeria was 42.00 kilocalories as of 2016 [17].

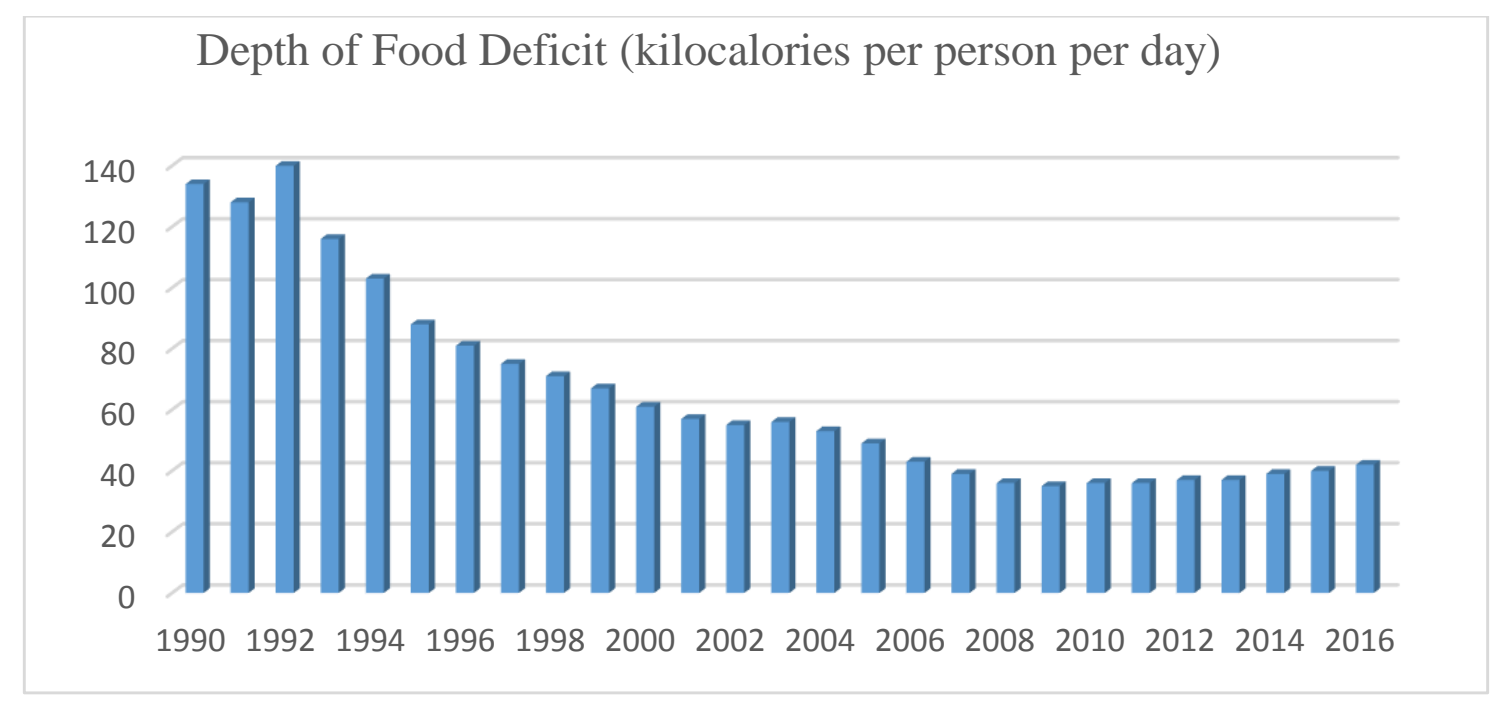

Fig. (3). Depth of Food Deficit in Nigeria (1990 - 2016).

Source: Author's computation using data from FAO, 2016.

\subsection{Empirical Literature}

Obilor examined the impact of Commercial Banks Credit to agriculture on Agricultural Development in Nigeria; this study underscored the importance of credit availability to the agricultural sector for adequate development pointing out that inadequate capital is a key factor for hampering attainment of food security in Nigeria [18]. Results from the 
study of Obilor showed that there exists a significant positive relationship between agricultural credit guarantee scheme fund and food production in Nigeria [18]. Also, the recommended that agricultural credit facility in terms of loans and other input supply should be easily accessible to farmers to encourage their participation in the agricultural sector which will increase production.

With the application of the Ordinary Least Squares (OLS) techniques analyzed the impact of commercial banks credit on agricultural productivity in Nigeria; the study concluded that there is a positive relationship between commercial banks' credit and agricultural productivity [19]. In a similar way Chris et al. focused on the significance of commercial banks credit on food availability [20]. The estimated results from this study showed that there exists a positive and significant relationship between agricultural credit guarantee scheme fund and agricultural production in Nigeria; their findings revealed a positive and significant relationship between commercial banks credit to the agricultural sector and food production in Nigeria. The result obtained indicated that an increase in commercial banks credit to agricultural sector will lead to an increase in agricultural production, hence food security in Nigeria. Interest rate which serves as a major factor in determining the desire for credit facilities was also examined. The authors found that a negative relationship exists between interest rate and agricultural output. This establishes that increasing interest rates may deter farmers and agricultural producers from borrowing funds, which may lead to declining output and reduced agricultural investment.

Bidisha et al. attempted to disentangle the relationship between credit, food security, and dietary diversity [21]. The study which was carried out through descriptive and econometric analysis focused on Bangladesh. The study found that access to credit facility tends to improve food security and allows households to achieve greater dietary diversity. They also find that greater calorie consumption per capita is more likely with households with access to credit.

O'Hara accessed how changes in the level of deposits in community banks influence total agricultural sales and direct-to-consumer agricultural sales of local food between 2002 and 2012, in rural states which includes North Dakota, South Dakota, Minnesota, Wyoming, and Montana [22]. The study finds that changes in community bank deposits had a positive impact on changes in direct-to-consumer agricultural sales of local foods. Also, total agricultural sales may not be impacted by changes in community bank deposits and that the consolidation of the commercial banking sector may influence the viability of farms in accessing credit.

\section{DATA SOURCE AND METHODOLOGY}

\subsection{Data Source}

The data for this study is obtained mainly from secondary sources, particularly from the 2016 World Bank (World Development Indicators). The time series data covered a period 1990-2016 and was used to estimate the specified model. The methods of analysis engaged in the study involve two main approaches, namely descriptive and econometric techniques.

The descriptive method was employed using tabular and graphical representations to show some indicators of food security in Nigeria. While the econometric analysis applied an econometric model that was fitted into data using the approach of the Autoregressive Distributed Lag (ARDL) Bounce testing procedure developed by Pesaran et al. to examine long-run relationship amongst population, agricultural productivity, and food security as well as short-run dynamics [23].

The bound test was adopted for four reason reasons stated thus; firstly, it does not require that the variables under study must be integrated of the same other, unlike the Johansen Cointegration approach. Secondly, the bound test is suitable for small or infinite sample data, unlike the conventional approach which requires a large sample size. Thirdly, it allows the cointegration relationship to be estimated using the Ordinary Least Square method, and lastly, the long and short run parameters of the model can be estimated simultaneously.

\subsection{Model Specification}

To investigate the association amongst credit facilities and food security in Nigeria, Depth of food deficit index is the explained variable as proxy for food security; while the explanatory variables are Agricultural Credit Guarantee Scheme Fund (AGCSF), Commercial Bank Credits to the agricultural sector (BCRED), and lending interest rate (LINTR) and total Population (POP) as shown in Table $\mathbf{1 .}$ 
Table 1. Description of variables.

\begin{tabular}{|c|c|c|c|}
\hline Symbol & Description & Measurement & Source \\
\hline DFD & Food Production Index as a proxy for food security & $\begin{array}{c}\text { Kilocalories per person per } \\
\text { day }\end{array}$ & $\begin{array}{c}\text { Food and Agricultural Organisation (FAO 2017) data } \\
\text { set }\end{array}$ \\
\hline POP & $\begin{array}{c}\text { Total Population } \\
\text { It captures the effect of population } \\
\text { growth on food security }\end{array}$ & Million & $\begin{array}{c}\text { World Development Indicators (WDI, 2016) of the } \\
\text { World Bank }\end{array}$ \\
\hline ACGSF & Agricultural credit guarantee scheme fund & Million & $\begin{array}{c}\text { World Development Indicators (WDI, 2016) of the } \\
\text { World Bank }\end{array}$ \\
\hline BCRED & $\begin{array}{c}\text { Agricultural credit facilities made vailable to } \\
\text { agricultural sector by commercial banks in form loans, } \\
\text { overdraft, etc for the purchase of agricultural materials }\end{array}$ & $\begin{array}{c}\text { Central Bank of Nigeria Statistical Bulletin (CBN } \\
\text { 2016) }\end{array}$ \\
\hline LINTR & Landing Interest rate & Percentage & Central Bank of Nigeria Statistical Bulletin (2016) \\
\hline
\end{tabular}

Source: Computed by the Researchers

Thus, the model for this stud is closely related to the study of Osabohien et al. (2018); hence, the model is expressed implicitly as expressed as;

$$
D F D t=f(P O P t, A C G S F t, B C R E D t, \text { LINTRt })
$$

Where:

$D F D$ represents food security, measured by the depth of food deficit in Nigeria; POP is the total population in Nigeria, ACGSF represents Agricultural credit guarantee scheme fund, BCRED represents Commercial bank credits in form of loans, etc made available to the agricultural sector, LINTR represents the lending interest rate, $\mu$ is stochastic term and $t$ is time.

The model can be represented in an explicit form as

$$
D F D_{t}=\beta_{0}+\beta_{1} P O P_{t}+\beta_{2} A C G S F_{t}+\beta_{3} B C R E D_{t}+\beta_{4} L I N T R t+\mu_{\mathrm{t}}
$$

Where;

$\beta 0$ is the Intercept, $\beta 1, \beta 2, \beta 3$, and $\beta 4$ are the coefficients of total population, agricultural credit scheme fund, bank credit, and lending interest rate respectively.

Thus, the expected signs of the coefficient of the explanatory variable are, $\beta 0>0, \beta 1<0, \beta 2>0, \beta 3>0$ and $\beta 4<0$. Hence, increase in the explanatory variables (except POP and LINTR) is expected to enhance the rate of food security, ceteris paribus.

\subsection{Method of Estimation}

The model for this study is hinged on bank credit channel theory. It explains who poses interest on credits through banks capital, particularly when banks' lending is constrained by a capital adequacy requirement [24]. Thus, an increase in interest rates will raise the cost of banks' external funding, but reduce banks' profits and capital. The tendency is for the banks to reduce their supply of loans if the capital constraint becomes binding. However, banks could also become more willing to lend during certain periods because of an improvement in their underlying financial condition.

To estimate the above formulated model, the study used time series data from 1990 to 2016 where there is availability of data for the variables [17]. The economic view package (E-views, version 10) was used in the estimation process. The ARDL model for equation (3) is specified as:

$$
\begin{aligned}
& \triangle D F D=\delta 0+\sum_{i=1}^{p} \delta 1 D F D \mathrm{t}-1+\sum_{i=0}^{p} \delta 2 \text { POPt }-1+\sum_{i=0}^{p} \delta 3 \triangle A C G S F \mathrm{t}-1+\sum_{i=0}^{p} \delta 4 \Delta B C R E D \mathrm{t} 1 \\
& +\sum_{i=0}^{p} \delta 5 \Delta L I N T R \mathrm{t}-1+\beta 1 \text { DFDt } 1+\beta 2 \text { POPt }-1+\beta 3 \text { ACGSF } \mathrm{t}-1+\beta 4 \text { BCREDt }-1+\beta 5 \text { LINTRt }-1+\mu \mathrm{t}
\end{aligned}
$$

Once cointegration is established, the long run relationship is estimated using the conditional ARDL model specified as:

$$
D F D=\delta_{0}+\beta_{1} D F D_{\mathrm{t}-1}+\beta_{2} P O P_{\mathrm{t}-1}+\beta_{3} A C G S F_{\mathrm{t}-1}+\beta_{4} B C R E D_{\mathrm{t}-1}+\beta_{5} L I N T R_{\mathrm{t}-1}+\mu_{\mathrm{t}}
$$


The short run dynamic relationship is estimated using the error correction model specified as:

$$
\begin{aligned}
& \Delta D F D=\delta_{0}+\sum_{i=1}^{p} \delta_{1} \Delta D F D_{\mathrm{t}-1}+\sum_{i=0}^{p} \delta_{2} P O P_{\mathrm{t}-1}+\sum_{i=0}^{p} \delta_{3} \Delta A C G S F_{\mathrm{t}-1}+\sum_{i=0}^{p} \delta_{4} \Delta B C R E D_{\mathrm{t}-1} \\
& \sum_{i=0}^{p} \delta_{5} \Delta L I N T R_{\mathrm{t}-1}+\alpha e c \mathrm{t}_{\mathrm{t}-1}+\mu_{\mathrm{t}}
\end{aligned}
$$

$\delta 0$ : Constant term; $\mu t$ means white noise, this captures other explanatory variables which are not explicitly captured in the model; $\delta 1-\delta 5$ represents the short-run elasticities (that is, coefficients of the first-differenced explanatory variables); $\beta 1-\beta 5$ represents the long-run elasticities (coefficients of the explanatory variables); $\mathrm{ecm}_{t-1}$ represents error correction term lagged for one period; $\alpha$ represents the speed of adjustment from short-run to long-run equilibrium in the event of shock; $\Delta$ represents first difference operator and P represents Lag length.

An F-test of the joint significance of the coefficients of the lagged levels of the variables was used to test the hypothesis of no cointegration amongst the variables against the presence of cointegration. The null hypothesis of no cointegration between credit facilities and food security given as:

$\mathrm{H} 0: \delta 1=\delta 2=\delta 3=\delta 4=\delta 5$

The alternative hypothesis was given as

H1: $\delta 1 \neq \delta 2 \neq \delta 3 \neq \delta 4 \neq \delta 5$

The F-test has a non-standard distribution irrespective of whether the variables are integrated at order 0 , which is [1(0)]; or order 1, that is [1(1)]. Pesaran et al. (2001) posited two sets of adjusted critical values that provide the lower and upper bounds used for inference. One set assumes that all variables are integrated at order 0 , that is [1(0)]; and the other assumes that they are all integrated at order 1 that is, [1(1)].

If the calculated F-statistics falls above the upper bound critical value, then the null hypothesis of no cointegration is rejected. If it falls below the lower bound, then the null hypothesis will be accepted. Finally, if it falls between the lower and upper bound, then the result would be inconclusive. The optimal lag length for the specified ARDL model was determined based on the Akaike Information Criterion (AIC).

\section{RESULTS AND DISCUSSIONS}

\subsection{The Unit Root Test for Stationarity}

The stationary test was conducted for the time series data using the Augmented Dickey-Fuller to determine the level of the unit root. Although, the bounds testing procedure does not require the pre-testing of the variables included in the model for unit roots owing to its suitability irrespective of whether the regressors in the model are purely integrated of 0 ; ie, I $(0)$, purely order $1[\mathrm{I}(1)]$ or mutually cointegrated. The application of unit root tests in the ARDL procedure might still be necessary in order to ensure that the variables are integrated of order one and none of the variables is integrated of order 2 or beyond because the computed F-statistics provided by [23] are valid for only variables that are $\mathrm{I}(0)$ or I(1). The Augmented Dickey-Fuller (ADF) test was used to investigate whether the variables used in this study have a unit root or not Table 2.

\begin{tabular}{|c|c|c|c|c|c|c|}
\hline \multirow{2}{*}{ Variable } & \multirow{2}{*}{$\begin{array}{c}\text { ADF Test } \\
\text { (a) level }\end{array}$} & \multirow{2}{*}{$\begin{array}{c}\text { ADF Test } \\
\text { (a) } 1^{\text {st }} \text { Difference }\end{array}$} & \multicolumn{3}{|c|}{ Mackinnon Critical Value } & \multirow{2}{*}{ Order of Integration } \\
\hline & & & $1 \%$ & $5 \%$ & $10 \%$ & \\
\hline DFD & -2.440 & -4.152 & -3.724 & -2.986 & -2.632 & $\mathrm{I}(1)$ \\
\hline POP & -0.584 & -3.529 & -4.440 & -3.632 & -3.254 & $\mathrm{I}(1)$ \\
\hline ACGSF & -3.878 & -1.252 & -4.498 & -3.658 & -3.268 & $\mathrm{I}(0)$ \\
\hline BCRED & 2.649 & -5.648 & $-3,724$ & -2.986 & -2.632 & $\mathrm{I}(1)$ \\
\hline LINTR & -3.821 & -6.376 & -4.440 & -3.632 & -3.254 & $\mathrm{I}(0)$ \\
\hline
\end{tabular}

Table 2. Estimates from the unit root test for stationarity.

Source: Computed by the Researchers via E-view software.

The Augmented Dickey-Fuller (ADF) unit root testing of the variables indicates that three of the variables which include DFD the depth of food deficit, POP total population, and BCRED Commercial bank loans attain their stationarity at the first difference which means that they are all integrated of order one while ACGSF Agricultural credit guarantee scheme fund and LINTR lending interest rate attain stationarity at level which means it was integrated of 
order zero. From the result above, the variables are not integrated at the same order, therefore, we conduct the Autoregressive Distributed Lag (ARDL) Bounce test [23].

\subsection{ARDL Bounce Test for Cointegration}

Cointegration test is employed to ascertain the long-run equilibrium relationship between Bank Credit and Food Security.

Table 3 above presents the ARDL bounds test results. Evidence from Table 3 shows that the F-statistic goes beyond the critical value of the upper bound at 5\% significance level, showing a co-integration amongst Bank Credit and Food Security meaning there exist a long run relationship between Bank credit and Food Security.

Table 3. ARDL bounce test.

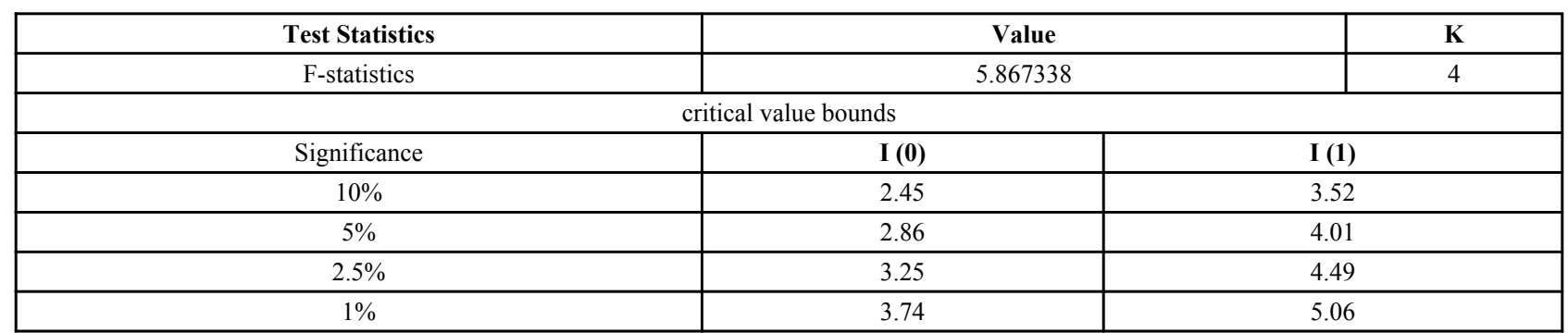

Source: Computed by the Researchers via E-view software.

Fig. (4) depicts the ARDL model selection using the Hannan-Quinn Criteria. The study employs the Hannan-Quinn Criteria to select the optimal model $[\operatorname{ARDL}(4,0,1,0,1)]$ to estimate the long-run and the short-run equilibrium relationship between the variables. Using the optimal model [ARDL $(4,0,1,0,1)$ ], the normalized co-integration equation for the ARDL regression analysis is expressed as:

Cointeq EC $=$ DFD-(-0.000001* POP +0.000002* ACGSF +0.081204*BCRED + 2.6498*LINTR -89.8085)

Based on the above, the results of the long-run and the short-run equilibrium relationship between Bank credit and Food Security are presented below.

Hannan-Quinn Criteria (top 20 models)

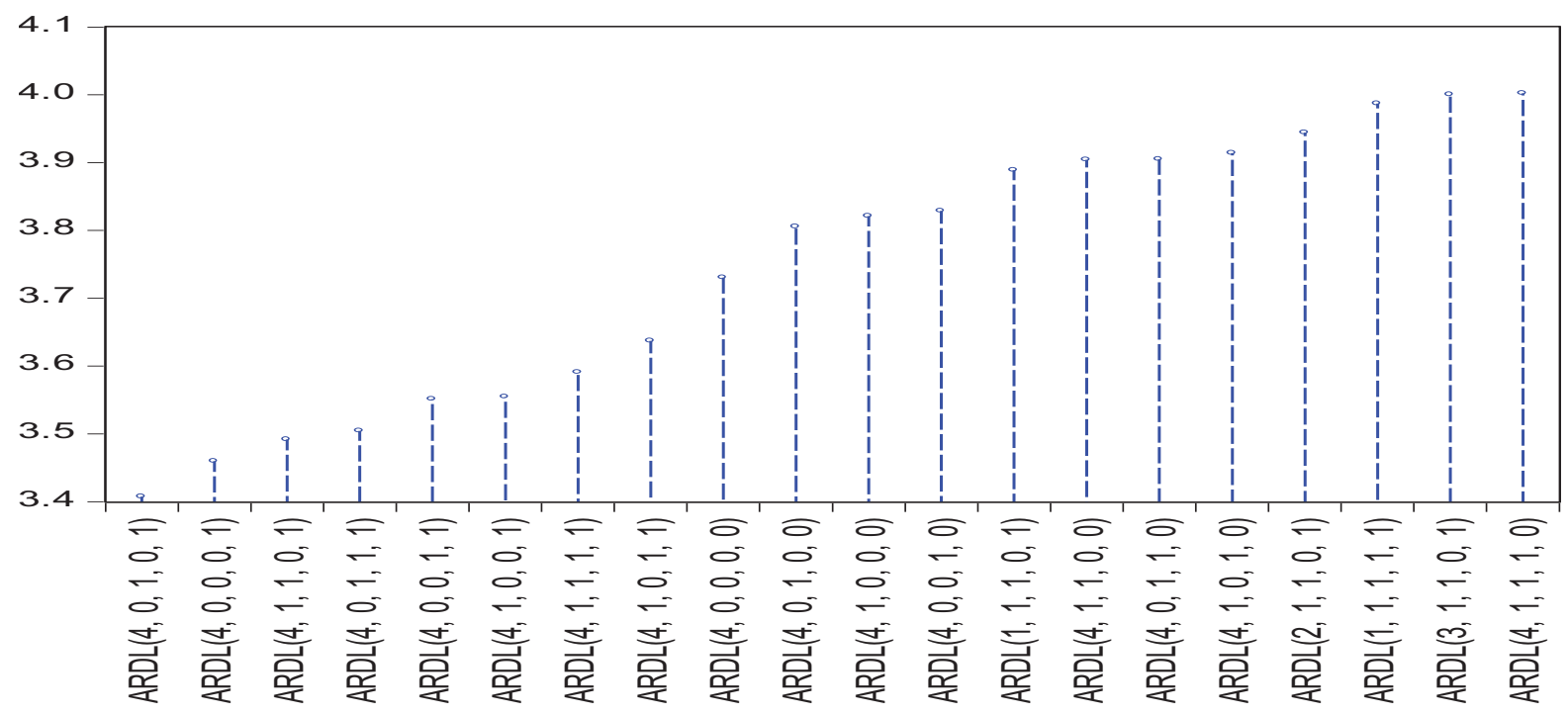

Fig. (4). ARDL model selection criterion.

The result of the estimated coefficients of the long run relationship in Table $\mathbf{4}$ indicates that Population has a negative influence on food security in Nigeria. The estimated coefficient of the population (-0.000001) implies that 1 unit increase in population will decrease food security by approximately 0.000001 unit all things being equal. 
Agricultural credit guarantee scheme fund was found to be positively related to food security with an estimated coefficient of 0.000002. This implies that a 1 unit increase in Agricultural credit guarantee scheme fund will lead to an increase of Food security by a magnitude of 0.000002 units.

Table 4. Long-run relationship estimation.

\begin{tabular}{|c|c|c|c|c|}
\hline Variables & Coefficient & Standard Error & T-Statistics & Pro-Value. \\
\hline POP & -0.00001 & 0.000000 & 0.0027 \\
\hline ACGSF & 0.002 & 0.000001 & 0.05751 \\
\hline BCRED & 0.081204 & 0.016550 & 4.906612 & 2.561735 \\
\hline LINTR & 2.649793 & 1.034374 & 1.786936 & 0.0004 \\
\hline C & 89.808490 & 50.258378 & 0.0992 \\
\hline
\end{tabular}

Source: Computed by the Researchers using E-view software.

Bank credit was found to be positively related to Food security with an estimated coefficient of (0.081204) which implies that 1unit increase in Bank credit will lead to an increase of Food security by 0.081204 units. The lending Interest rate was found to be positively related to Food security with an estimated coefficient of (2.5449793) which implies that 1 unit increase in Gross fixed capital formation will lead to an increase of Food security by 2.649793 unit. All variables were statistically significant at their respective level of significance. All variables apart from Lending Interest rate meet the a priori expectation.

The results of this study closely follow [25] in the area that improved level of credit given to farmers enhances the productivity level of the agricultural sector and thus lead to an increase in the level of food security in Nigeria as seen in ARDL result. This study is also in line with [26] where it was believed that access to agricultural credit to farmers increases their production capacity which in turn lead to food security, also aggress with [27] where it was pointed out that there exists a significant positive relationship between food security and the availability of agricultural credit to farmers. His study noted that one percent increase in the availability of agricultural credit to farmers amounted to a $2.5 \%$ and increase in agricultural productivity in Nigeria, this, of course, follows the apriori expectations. Also, the study of [28] finds that in Pakistan, small-scale farmers close to 76\% of credit received from both formal and informal sources to improve their farm practices, thus, this was observed to increase agricultural productivity by $69 \%$ in the country.

From Table 5 above the coefficient of the error correction model ECM (-1) is $(-0.180296$ which satisfy the condition of being negative and lie between 0 and 1 . This indicates in an event of disequilibrium, there is a tendency for the economy to return to equilibrium in the long run with a speed of $18 \%$.

Table 5. Short run relationship estimation.

\begin{tabular}{|c|c|c|c|c|}
\hline Variables & Coefficient & Std. Error & T-Statistics & -2.137699 \\
\hline D(POP) & -0.000000 & 0.000000 & 0.0538 \\
\hline D(ACGSF) & -0.000000 & 0.000000 & 0.6518 \\
\hline D(BCRED) & -0.014641 & 0.005532 & 0.462806 \\
\hline D(LINR) & 0.047612 & 0.129959 & 0.0213 \\
\hline ECM $(-1)$ & -0.180296 & 0.051139 & 0.7205 \\
\hline
\end{tabular}

Source: Computed by the Researchers via E-view software.

\subsection{Diagnostic Test and Stability Test}

The ARDL model was validated and verified using a series of diagnostic and stability check to scrutinize the independence of the residuals from the fitted model. For a robust ARDL model, the residuals must exhibit the required independence during the diagnostic and stability checks, if not, the model is unacceptable statistically and requires further model modification before additional diagnostic and stability checks [23].

In this way, the ARDL model becomes unbiased and robust to make the correct statistical inferences. Diagnostic tests employed to validate the ARDL model include; Heteroskedasticity Test, Jarque-Bera Test and Ramsey RESET Test as presented in Table $\mathbf{6}$ below.

ARDL residual heteroskedasticity was tested with Breusch-Pagan-Godfrey Test statistic [29]. The result showed that the Probability value of the observed R-squared is greater than $5 \%$ this means we accept the null hypothesis which indicates no heteroskedasticity. 
Table 6. Diagnostic test results.

\begin{tabular}{|c|c|c|c|}
\hline \multicolumn{5}{|c|}{ Heteroskedasticity Test: Breusch-Pagan-Godfrey } \\
\hline F-Statistics & 0.806918 & Prob. F (19,10) & 0.6279 \\
\hline Obs*R-squared & 9.247573 & Prob. Chi-Square (19) & 0.5088 \\
\hline Scaled explained SS & 1.973829 & Prob. Chi-Square (19) & 0.9965 \\
\hline \multicolumn{7}{|c|}{ JARQUE-BERA TEST } \\
\hline Jarque-Bera & 0.242205 & Probability & P-Value \\
\hline \multicolumn{7}{|c|}{ RAMSEY RESET TEST } \\
\hline
\end{tabular}

Source: Computed by the Researchers via E-view software.

ARDL residual normal distribution was tested with Jarque-Bera test statistic. Evidence from Table $\mathbf{5}$ shows that the null hypothesis of multivariate normal distribution was accepted at the 5\% significance level, this means that; the ARDL residuals are normally distributed. ARDL functional misspecification was estimated with Ramsey RESET Test statistic. Findings show that the probability level is greater than $5 \%$, therefore, we accept the null hypothesis, meaning that there the ARDL model is in its functional form [29].

\subsection{Stability Test}

To estimate the structural stability of the equation in the ARDL model, the study employed the CUSUM (Cumulative Sum test) and CUSUM (Cumulative Sum of Squares residual tests).

Fig. (5) shows the CUSUM and CUSUM of Squares residual tests of the ARDL Model. Evidence from Fig. (5) shows that all the plots in CUSUM and CUSUM of Squares residual test lie within the 5\% significance level. Meaning that the estimated parameters of the equation in the ARDL model are constant and stable to verify and validate the evidence of ARDL cointegration bound test, the long-run and short-run relationship. In other words, the ARDL model is robust and meets stability conditions to make unbiased statistical inferences [30].
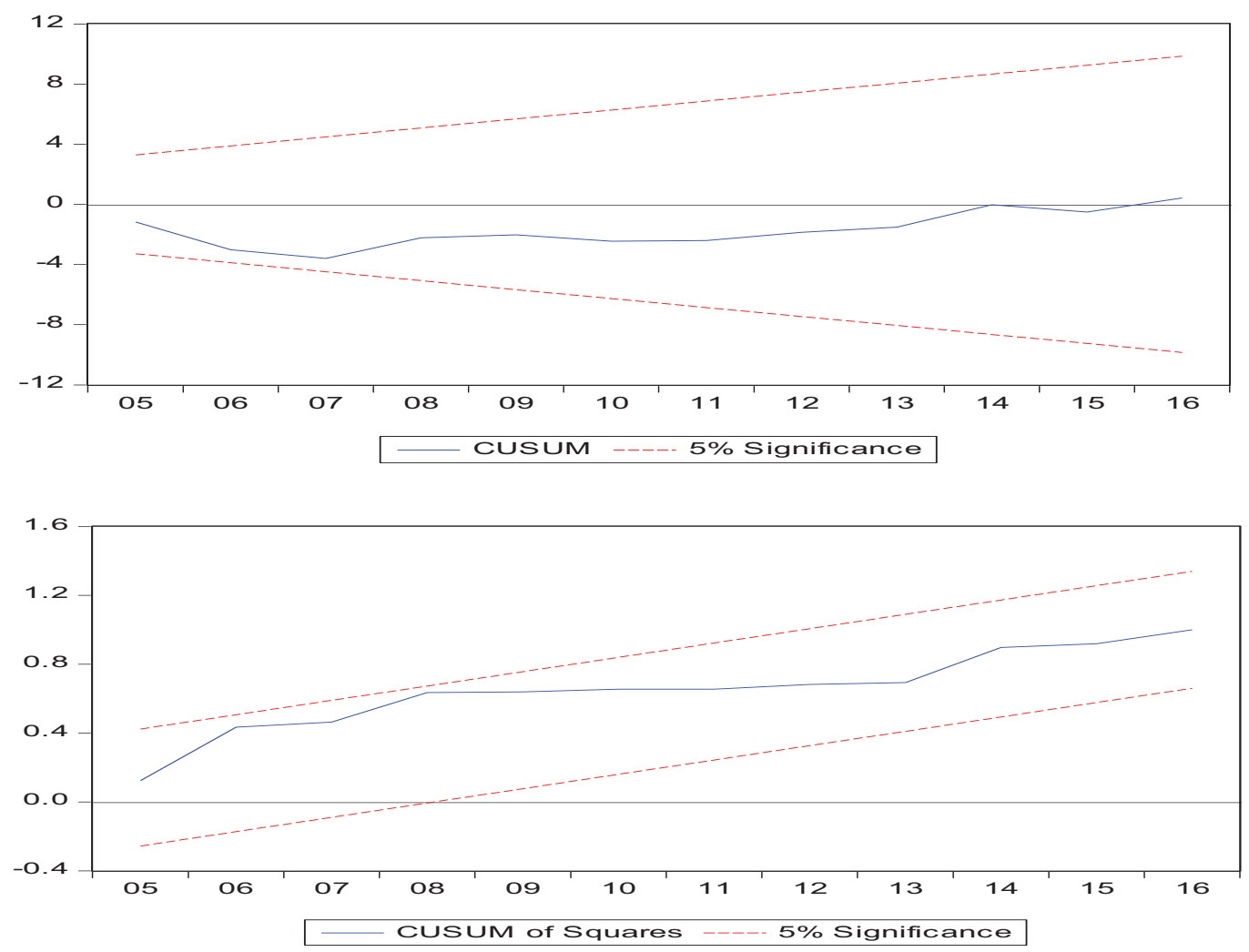

Fig. (5). Test of Model Stability. 


\section{SUMMARY AND CONCLUSION}

This study was motivated to examine the long-run relationship between agricultural credit facilities and food security in Nigeria. The study observed that farmers in Nigeria, especially those in rural communities generate approximately $75 \%$ of food production in most states of the country. In line with this, two agricultural credit facilities were considered in this study: commercial banks credit to farmers and the agricultural credit guarantee scheme fund, as credit facilities have been recognised to increase farmers production which will enable them to grow food and feed the teeming population.

Also, these credit facilities aim to enable farmers in rural communities to acquire skills and enhance their farming strategies in improving farm production; to enable institutions involved in providing microcredit provision are supporting them to improve their livelihood through expansion of the capital base.

Generally, in developing countries, lack of access to credit pose a limitationon on smallholders' investment and consequently, for agricultural production as well as income creation for farmers in particular and the government in general. Microcredit in Nigeria is unarguably seen as an effective strategy with the potential of improving food insecurity in the country. In order to achieve this objective in Nigeria, the opportunities of accessing credit facilities to farmers need to be increased and the volume also should be expanded, no doubt, this strategy will contribute immensely in reducing constraints to capital and improve the level food security.

Furthermore, placing the Sustainable Development Goal 2; which aims at eliminating hunger and achieve sustainable food security globally by year 2030: in line with that, this study, was also motivated by the need to contribute to the frontiers of knowledge and enlighten policy makers in propounding policies and programmes that will help to overcome the issue of food security, as the study examined the potential of commercial bank credit to agriculture and agricultural credit guarantee scheme fund towards improving food security in Nigeria, the aspect of population was also considered as it was argued that the rate of population growth in a country affects the state of food security in such country; it also examined the effect of lending rates of credits to agriculture on food security in Nigeria. The results from the ARDL confirmed that credit facilities such as commercial bank credits to the agricultural sector and agricultural credit guarantee scheme fund are needed in increasing the state of food security in Nigeria.

Therefore based on the results obtained, this study recommended that: policies on proper and a wide coverage of education on family planning should be implemented; this is based on the negative impact of population on the state of food security in Nigeria. Secondly, the positive impact of agricultural credit guarantee scheme fund and commercial banks credit to food security calls for an appropriate financing of the ACFSF by the government and monitor commercial banks lending interest rates imposed on credit facilities. In this regards, the government should continue to serve as guarantors for loans given to farmers as this will encourage the banks to lend more to farmers.

Also, the positive impact of commercial banks' credit to food security draws attention to the importance of allocating more credit to the agricultural sector in Nigeria. This can be done by the central bank of Nigeria (CBN) through lowering of the interest rate charged on farmers for money borrowed for agricultural activities.

Similarly, the negative effect of interest rate on agriculture production also draws attention on the need to implement effective policy in lowering the rate of interest charged by commercial banks to farmers, the lowering of interest rate will enable bankers to reach a wider spread and allow more funds to farmers for the purpose of agricultural investment thus eroding the depth of food deficit.

\section{CONSENT FOR PUBLICATION}

Not applicable.

\section{CONFLICT OF INTEREST}

The authors declare no conflict of interest, financial or otherwise.

\section{ACKNOWLEDGEMENTS}

The authors appreciate the funding received from the Covenant University Centre for Research, Innovation and Discovery(CUCRID). Also, the authors appreciated deeply the comments received from the anonymous reviewers which helped in improving the quality of the study. 


\section{REFERENCES}

[1] Osabohien R, Osabuohien E, Urhie E. Food security, institutional framework and technology: Examining the nexus in nigeria using ardl approach. Curr Nutr Food Sci 2018; 14(2): 154-63. [http://dx.doi.org/10.2174/1573401313666170525133853] [PMID: 29853816]

[2] Osabohien R, Osuagwu E. Social protection policies and agricultural output in nigeria: Empirical investigation using household survey data. 4th Covenant University International Conference on E-Governance in Nigeria (CUCEN). May 7-9, 2017;

[3] Malthus TR. An essay on the principle of population as it affects the future improvement of society, with remarks on the speculations of Mr Godwin, M Condorcet, and other writers. London: Johnson 1798.

[4] Simtowe F, Zeller M, Phiri A. Determinants of moral hazard in microfinance: Empirical evidence from joint liability lending programs in malawi. Afr Rev money finance bank 2006; 5-38.

[5] Petrick M. Credit rationing of Polish farm households: A theoretical and empirical analysis (No 26). Studies on the Agricultural and Food Sector in Central and Eastern Europe 2004.

[6] Institute of Statistical, Social and Economic Research (ISSER). Annual Report 2010-2011.

[7] Abdul-Jalil MA. Determinants of access to credit and its impact on household food security in Karaga district of the Northern region of Ghana Doctoral dissertation submitted to the Department of Agricultural Economics, Agribusiness and Extension, Kwame Nkrumah University of Science and Technology, Ghana 2015.

[8] Matthew O, Osabohien R, Fasina F, Fasina A. Greenhouse gas emissions and health outcomes in Nigeria: Empirical insight from ardl technique. Int J Energy Econ Policy 2018; 8(3): 43-50.

[9] Ejemeyovwi JO, Osabuohien ES, Osabohien R. ICT investments, human capital development and institutions in ECOWAS'. Int J Econ Bus Res 2018; 15(4): 463-74.

[http://dx.doi.org/10.1504/IJEBR.2018.092151]

[10] Duong PB, Izumida Y. Rural development finance in Vietnam: A micro-econometric analysis of household surveys. World Dev 2002; 30(2): 319-35. [http://dx.doi.org/10.1016/S0305-750X(01)00112-7]

[11] Osabuohien E, Obiekwe E, Urhie E, Osabohien R. Inflation rate, exchange rate volatility and exchange rate pass-through Nexus: The Nigerian experience. J Appl Econ Sci. Volume XIII 2018; 2(56): 574-85.

[12] Shephard WG. Market Power and Economic Welfare. New York: Random House 1979.

[13] Singh I, Squire L, Strauss J. Agricultural household models: Extensions, applications, and policy. The World Bank 1986.

[14] Sadoulet E, De Janvry A, Davis B. Cash transfer programs with income multipliers: PROCAMPO in Mexico. World Dev 2001; 29(6): 1043-56. [http://dx.doi.org/10.1016/S0305-750X(01)00018-3]

[15] Stiglitz JE. More instruments and broader goals: Moving toward the Post-Washington Consensus. Wider perspectives on global development. London: Palgrave Macmillan 2005; pp. 16-48. [http://dx.doi.org/10.1057/9780230501850_2]

[16] Central Bank of Nigeria Statistical Bulletin-CBN, Volume 27, December 2016.available at http:// statistics.cbn.gov.ng/ cbn-onlinestats

[17] Food and Agriculture Organisation-FAO. World Agriculture: Towards 2015/2030. FAO Corporate Document Repository 2017.

[18] Obilor SI. The impact of commercial banks' credit to agriculture on agricultural development in Nigeria: An econometric analysis. Int J Bus Humanit Tech 2013; 3(1): 85-94.

[19] Anyanwu FA, Ananwude AC, Okoye NT. Empirical assessment of the impact of Commercial Banks' lending on economic development of Nigeria. Int J Appl Econ Finance Acc 2017; 1(1): 14-29.

[20] Chris OU, Mbat DO, Stephen BD. The effect of Commercial Banks' credit on agricultural production in Nigeria 2016.

[21] Bidisha SH, Khan A, Imran K, Khondker BU, Suhrawardy GM. Role of credit in food security and dietary diversity in Bangladesh. Econ Anal Policy 2017; 53: 33-45. [http://dx.doi.org/10.1016/j.eap.2016.10.004]

[22] O'Hara JE. Community Bank credit and agricultural sales in the rural states. Rev Reg Stud 2017; 47(2): 137-52.

[23] Pesaran MH, Shin Y, Smith RJ. Bounds testing approaches to the analysis of level relationships. J Appl Econ 2001; 16(3): 289-6. [http://dx.doi.org/10.1002/jae.616]

[24] Van den Heuvel SJ. Does bank capital matter for monetary transmission? Econ Policy Rev 2002; 8(1): 259-65.

[25] Udoka. The effect of Commercial Banks' credit on agricultural production in Nigeria. Journal of Finance and Accounting 2016; 4(1): 1-10.

[26] Paul AL, Amarachi NA, Oyedele MO, Odafe ME, Juliana AA. Factors affecting the investment climate, SMEs productivity and entrepreneurship in Nigeria. Eur J Sustain Dev 2018; 1(7): 182-200.

[27] Ojiya EA, Okoh SA, Mamman AB, Chukwuemeka NJ. An empirical analysis of the effect of agricultural input on Agricultural productivity in Nigeria. Int J Agric Sci Food Technol 2017; 3(4): 77-85. 
[28] Hussain A, Thapa GB. Smallholders' access to agricultural credit in Pakistan. Food Secur 2012; 4(1): 73-85. [http://dx.doi.org/10.1007/s12571-012-0167-2]

[29] Breusch TS, Pagan AR. A simple test for heteroscedasticity and random coefficient variation. Econometrica 1979; 1287-94. [http://dx.doi.org/10.2307/1911963]

[30] Ploberger W, Krämer W. The CUSUM test with OLS residuals. Econometrica 1992; 271-85. [http://dx.doi.org/10.2307/2951597]

\section{(C) 2018 Osabohien et al.}

This is an open access article distributed under the terms of the Creative Commons Attribution 4.0 International Public License (CC-BY 4.0), a copy of which is available at: (https://creativecommons.org/licenses/by/4.0/legalcode). This license permits unrestricted use, distribution, and reproduction in any medium, provided the original author and source are credited. 